\title{
Fatigue and Associated Factors in Multiple Sclerosis Patients in Latvia
}

\author{
S. Šetlere* \\ A. Abelsen** \\ D. Pastare $* * *$ \\ A. Millers*** \\ *Department of Neurology, \\ Pauls Stradins Clinical \\ University Hospital; \\ Faculty of Further Education, \\ Riga Stradins University \\ **Faculty of Medicine, \\ Riga Stradins University \\ ***Department of Neurology, \\ Pauls Stradins Clinical \\ University Hospital; \\ Department of Neurology \\ and Neurosurgery, \\ Riga Stradins University
}

\begin{abstract}
Summary. Background and objectives. Fatigue is one of the most common symptoms of multiple sclerosis (MS). The aim of this study was to determine the presence of fatigue in MS patients in Latvia and its relation to lifestyle factors, neurological disability and depression.

Material and methods. This cross-sectional study included 117 participants (44 patients with MS and 73 healthy control group). Applied research instruments were: Expanded Disability Status Scale (EDSS), Patient Health Questionnaire (PHQ-9), Fatigue Severity Scale (FSS), and the general questionnaire for the collection of socio-demographic, lifestyle habits and clinical data constructed for the purposes of this study.

Results. Mean FSS score was 3.9 1.9 in MS group. 26 (59.1\%) patients had FSS score of 3.8 or more and were classified as a fatigue group (MSF) while 18 (40.9\%) patients had FSS of 3.7 or less and were classified as a non-fatigue (MSNF) group. There was statistically significant difference between MSF and MSNF groups considering PHQ-9 score $(p=0.019)$, FSS score $(\mathrm{p}<0.001)$ and EDSS score $(\mathrm{p}<0.001)$. Significant correlations of fatigue with depression $(r=0.48, p=0.001)$, fatigue with neurological disability $(r=0.49, p=0.001)$ and fatigue with smoking $(\mathrm{r}=0.29, \mathrm{p}=0.054)$ were confirmed.

Conclusions. Fatigue is a common symptom in MS patients in Latvia. This study supports significant association between fatigue and clinical factors (disability, depression) and modifiable lifestyle factor - smoking.
\end{abstract}

Keywords: multiple sclerosis, fatigue, depression.

\section{INTRODUCTION}

Multiple sclerosis (MS) is a chronic, immune-mediated demyelinating disease of the central nervous system (CNS). It affects 2.3 million people worldwide, and is the most common cause of non-traumatic disability in young adults [1]. In 2015 there were 1801 patients registered in Latvia with MS diagnosis.

Fatigue is one of the most common symptoms of multiple sclerosis (MS). Thirty percent of patients present with fatigue, and it affects up to $90 \%$ of patients at some point

\footnotetext{
Adresas:

Signe Šetlere

Department of Pediatric Neurology and Neurosurgery,

Children's Clinical University Hospital

Vienibas iela 45, LV-1004 Riga, Latvia

E-mail: signe.setlere@gmail.com
}

during their illness [1-3]. MS patients suffering from fatigue describe it as one of the worst and most debilitating symptom [4]. It is a common cause of early unemployment among these individuals, and has a negative impact on the quality of life $[5,6]$. Due to the above-mentioned reasons, appropriate and effective management is very important.

In MS, fatigue can be divided into primary and secondary fatigue. Secondary fatigue is not an alternative diagnosis but may rather coexist and can contribute to the overall fatigue, but if recognized, secondary fatigue can be minimized [7, 8]. It is known that patients with MS are found to have a lifetime prevalence of depressive disorders of up to $50 \%$ [9], which is significantly higher than the $12.9 \%$ lifetime prevalence among patients with other chronic medical conditions [10]. Fatigue may arise independently of depression, or it can be an integral symptom.

Separation of treatable from untreatable causes of fatigue can be challenging in MS, however, the wide range of

(C) Neurologijos seminarai, 2018. Open Access. This article is distributed under the terms of the Creative Commons Attribution 4.0 International License CC-BY 4.0 (http://creativecommons.org/licenses/by/4.0/), which permits unrestricted use, distribution, and reproduction in any medium, provided you give appropriate credit to the original author(s) and the source, provide a link to the Creative Commons license, and indicate if changes were made. 
potential etiologies within this population makes MS a unique model for the study of fatigue [4]. The present study was designed in order to determine the presence of fatigue in multiple sclerosis patients and its relation to lifestyle factors, neurological disability and depression.

\section{METHODS}

This cross-sectional study included 117 participants (44 patients with MS and 73 healthy control group) who were assessed consecutively between 1st October 2015 and 31st January 2016. The study dealt with 44 patients with relapsing-remitting MS aged 20-69 years, who were treated at the Center of Multiple sclerosis, Pauls Stradins Clinical University Hospital in Riga. Inclusion criterion was a definitive diagnosis of MS based on the McDonald's criteria [11]. Patients were excluded if they had the progressive type of the disease or had a relapse during the 30-day period before being included in this study. Control group was made of 73 healthy individuals matched for age and gender. The ones diagnosed with multiple sclerosis, chronic fatigue syndrome, and hepatitis $\mathrm{B}$, as well as nonresidents of Latvia were excluded.

Applied research instruments were: Expanded Disability Status Scale (EDSS) [12], Patient Health Questionnaire (PHQ-9) [13], Fatigue Severity Scale (FSS) [2], and the general questionnaire for the collection of socio-demographic, lifestyle habits and clinical data constructed for the purposes of this study. It included information on age, gender, education, level of disability, fatigue severity, depression scores and lifestyle factors (average hours of sleep, pet ownership, smoking, alcohol consumption, daytime sleeping, and physical activity).

All patients were examined at the time of recruitment. They underwent complete neurological examination. Physical disability was assessed using the Expanded Disability Status Scale (EDSS) [12]. Scores for the total scale can range from 0 (no neurological abnormality) to 10 (death from multiple sclerosis). Patients with a score of $\leq 3.5$ were defined as fully ambulatory while patients with higher scores had ambulation limitations.

Level of depression was measured by the Patient Health Questionnaire (PHQ) which is a self-report measure for major depressive and subclinical depressive disorders and has been frequently used and extensively validated in multiple populations. The PHQ-9 queries each of the Diagnostic and Statistical Manual of Mental Disorders IV (DSM-IV) major depression criteria. The items address the past 2 weeks and are scored on a 4-point scale $(0=$ not at all, $1=$ several days, $2=$ more than half the days, and 3 = nearly every day). A score of 10 or higher indicates major depression (mild), 15 or higher moderate, and $>20$ severe major depression $[13,14]$.

Fatigue was measured by the Fatigue Severity Scale (FSS) which shows high reliability, validity, and internal consistency [2] and has been the most widely used in MS studies [15]. It comprises nine items, each scored from
1-7 on a Likert scale, where 1 signifies no symptoms of fatigue and 7 indicates severe fatigue. Based on the mean results of control group, we considered a status of 'fatigue' when the FSS score was $\geq 3.8$, and a status of 'non-fatigue' with score $<3.7$.

The same questionnaires were distributed to the control group.

Ethics approval was granted by Ethics Committee of Riga Stradins University.

The Shapiro-Wilk test was used to test the continuous data for normal distribution. The independent Mann-Whitney $U$ test was used to test for equal distribution between the control group and MS group. The cases were recorded into age groups (20-35, 36-50, 51-65, and >65) and compared in regards to difference in distribution of the FSS score, PHQ-9 score, and average hours of sleep during the night (between control and MS group).

The Pearson's and The Spearman rank correlation coefficients, Mann Whitney U and Chi-square tests were used. All statistical tests were two-sided, and P-value less than 0.05 was considered as significant.

\section{RESULTS}

In total, we investigated 117 participants, 44 MS patients and 73 healthy controls. The mean age of the patients was $42.9 \pm 12$ years. $28(63.6 \%)$ of the patients were female. The average EDSS score of the MS patients was 2.8 \pm 1.7 .

Table 1.1 shows the comparison of demographic characteristics and education level between the MS patients and healthy controls.

We compared age, fatigue, depression levels and sleep duration between MS patients and control group (Table 1.2). Mean FSS score in MS group was 3.9 \pm 1.9 , but in control group 3.84 \pm 1.2 . PHQ-9 score in MS group was higher $(7.7 \pm 5.3)$ than in control group $(5.1 \pm 3)$. Average hours of sleep in both groups were similar - 7.22 and 7.23 hours.

Table 1.1. Comparison between patients with MS and controls: gender, education level

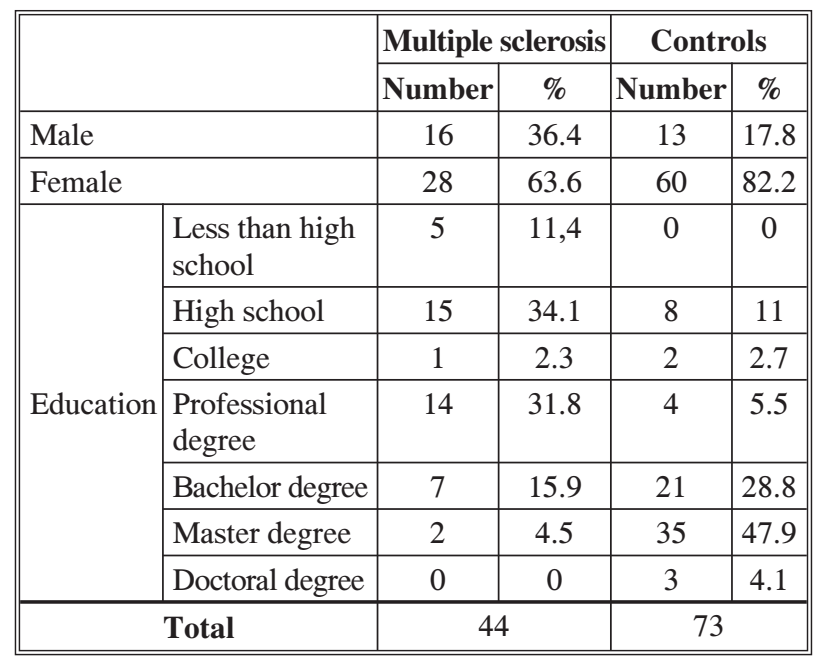


Table 1.2. Comparison between patients with MS and controls: age, fatigue, depression and sleep duration

\begin{tabular}{||l|c|c||}
\hline & Multiple sclerosis & Controls \\
\hline & Mean \pm SD & Mean \pm SD \\
\hline Age & $42.9 \pm 2.0$ & $38 \pm 2$ \\
FSS & $3.9 \pm 1.9$ & $3.84 \pm 1.2$ \\
PHQ-9 & $7.7 \pm 5.3$ & $5.1 \pm 3$ \\
Average hours of sleep & 7.22 & 7.23 \\
\hline
\end{tabular}

SD: standard deviation, FSS: Fatigue Severity Scale, PHQ-9: Patient Health Questionnaire

We compared lifestyle habits in both groups (Table 1.3). Regarding pet ownership, $63.6 \%$ of MS patients own a pet if compared to control group where only $31.5 \%$ have one. Sleeping habits in both groups are similar $11.4 \%$ in MS group and $12.3 \%$ in control group sleep during the day. Physical activity level in MS patient group is lower $(34.1 \%)$ than in control group (56.2\%). $31.8 \%$ of MS patients are smokers, whereas only $17.8 \%$ of control group smoke. However, in control group $47.9 \%$ of people consume alcohol at least twice a week while in MS patient group $90.9 \%$ consume alcohol less than once a week.

$26(59.1 \%)$ patients had FSS score of 3.8 or more and were classified as a fatigue group (MSF) while 18 (40.9\%) patients had FSS of 3.7 or less and were classified as a non-fatigue (MSNF) group. The mean FSS score for MS group was $3.9 \pm 1.9$. In control group $53.4 \%(n=39)$ were fatigued while $46.6 \%(n=34)$ were not.

There was statistically significant difference between fatigue (MSF) and non-fatigue (MSNF) groups considering PHQ-9 score $(\mathrm{p}=0.019)$, FSS score $(\mathrm{p}<0.001)$ and EDSS score $(\mathrm{p}<0.001)$ (Table 2$)$.

We explored the association between fatigue in MS and demographic factors, education level, disability, depression and lifestyle factors. Significant correlations of fatigue with depression $(r=0.48, p=0.001)$ and fatigue with neurological disability measured by EDSS scale $(r=0.49$, $\mathrm{p}=0.001$ ) was confirmed (Fig. 1,2). There was weak positive correlation between fatigue and smoking $(r=0.29$, $\mathrm{p}=0.054$ ) found in patients with MS. Moderate, positive,

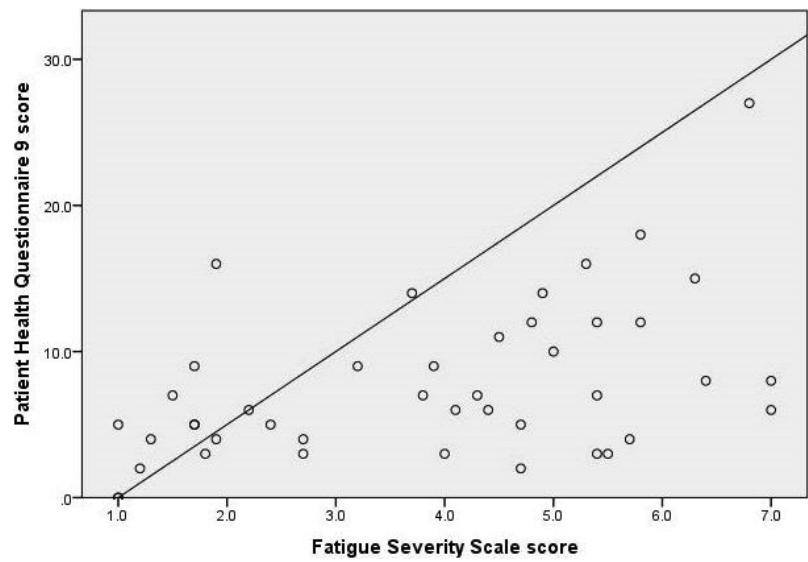

Fig. 1. Correlation between fatigue (FSS score) and depressive symptoms (PHQ-9 score) in multiple sclerosis patients
Table 1.3. Comparison between MS and healthy controls: pets, smoking, daytime sleeping, physical activity, alcohol consumption habits

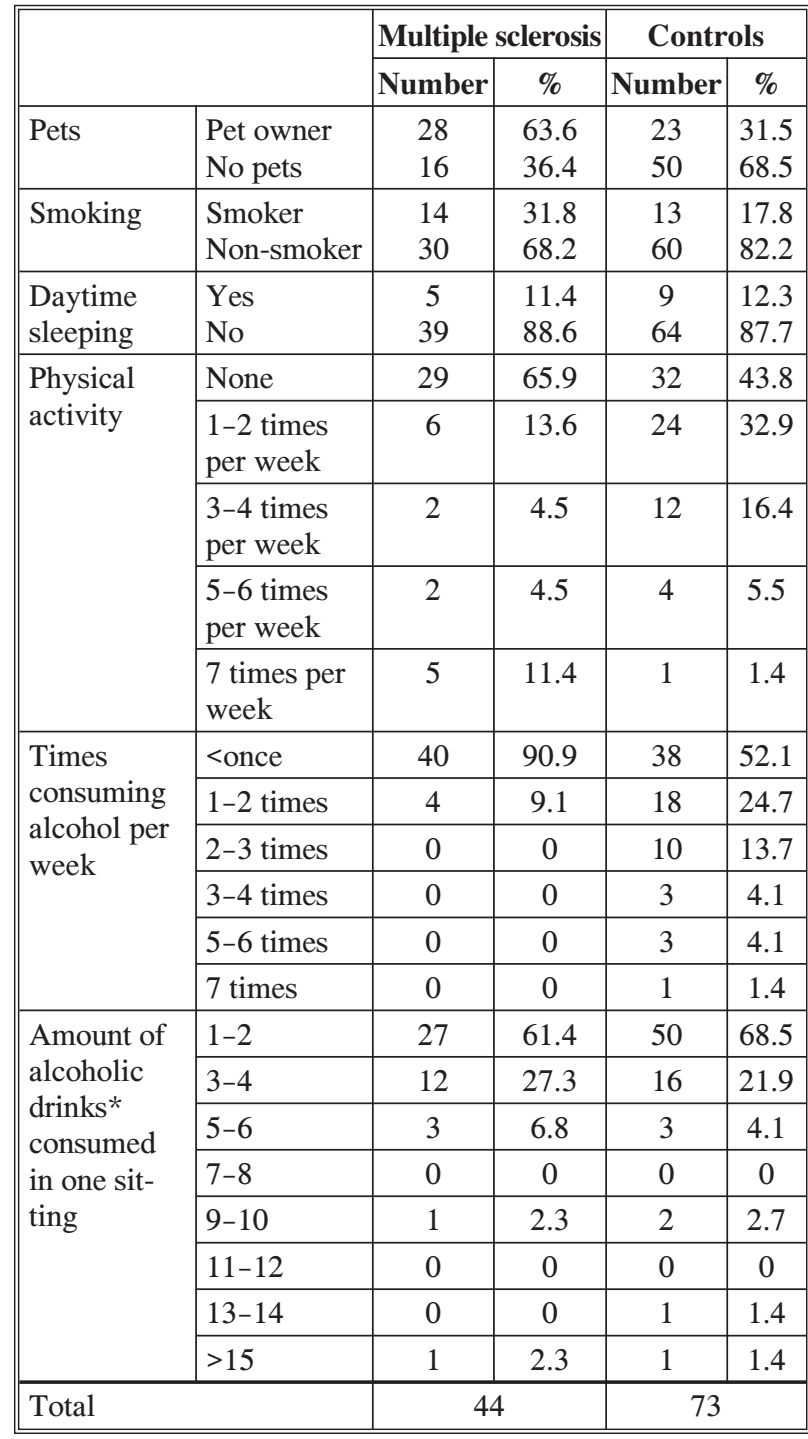

*defined as $500 \mathrm{ml} 5 \%$ beer OR $150 \mathrm{ml}$ / one glass of $11 \%$ wine OR $50 \mathrm{ml} 40 \%$ spirits

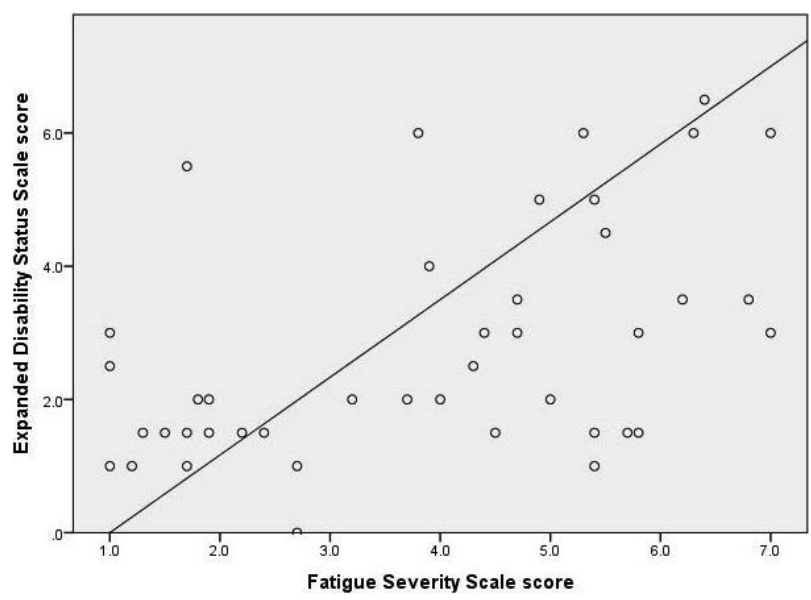

Fig. 2. Correlation between fatigue (FSS score) and neurological disability (EDSS score) in multiple sclerosis patients 
Table 2. Relationship between fatigue and clinical characteristics in MS patients

\begin{tabular}{|l|c|c|c||}
\hline & MSF (n=26) & MSNF (n=18) & P value \\
\hline PHQ-9 score & 25.76 & 16.78 & 0.019 \\
FSS score & 31.5 & 9.5 & $<0.001$ \\
EDSS score & 27.15 & 13.97 & $<0.001$ \\
\hline
\end{tabular}

MS: Multiple Sclerosis, MSF: Multiple Sclerosis fatigue group, MSNF: Multiple Sclerosis Non Fatigue group, PHQ-9: Patient Health Questionnaire 9, FSS: Fatigue Severity Scale, EDSS: Expanded Disability Status Scale

statistically significant correlation of disability with depression $(\mathrm{r}=0.38, \mathrm{p}=0.012)$ was also confirmed in MS group. In control group there was a significant correlation between fatigue and depression.

We did not find any association between fatigue and demographic factors, education level, sleeping habits, physical activity, alcohol consumption and pet ownership.

In this study, $27.9 \%(n=12)$ of the MS patients were depressed, only $8.2 \%(n=6)$ of the controls were depressed. There was a significantly higher FSS score $(\mathrm{p}=0.008)$ in depressed MS patients (Fig. 3).

\section{DISCUSSION}

Our study provides a unique, preliminary analysis of associations between demographic, clinical and lifestyle factors and clinically significant fatigue in Latvian population with MS.

In this study, $59.1 \%$ of the MS patients were fatigued. This number is close to that found in the international fatigue prevalence part of the HOLISM (Health Outcomes and Lifestyle Intervention in a Sample of People with Multiple Sclerosis) study with 2138 participants, where $65.6 \%$ of the participants were fatigued [16].

Identification of modifiable factors that may contribute to fatigue has been the subject of recent studies. We analyzed the association between fatigue and lifestyle factors that might minimize or exacerbate fatigue and found a tendency in our study which showed that smoking patients were more fatigued than non-smokers $(p=0.054) .71 .4 \%$ of smoking patients were fatigued while only $53.3 \%$ of nonsmokers were fatigued. In a study by Fritz et al. [17], it was demonstrated that smokers, over time, had an increased rate of brain atrophy compared to non-smoking controls. The brain atrophy in MS is accelerated comparing to healthy controls [18], and smoking has been shown to worsen MS [19]. Considering facts mentioned above, MS patients could benefit from smoking cessation.

No significant associations were found between alcohol consumption habits and fatigue in our study. In the HOLISM study [16], moderate consumption of alcohol was associated with lower odds of fatigue. All of the MS patients in our study consumed alcohol less than twice a week, $90.9 \%$ less than once per week, and most of them less than four alcoholic beverages per week (88.7\%). Be-

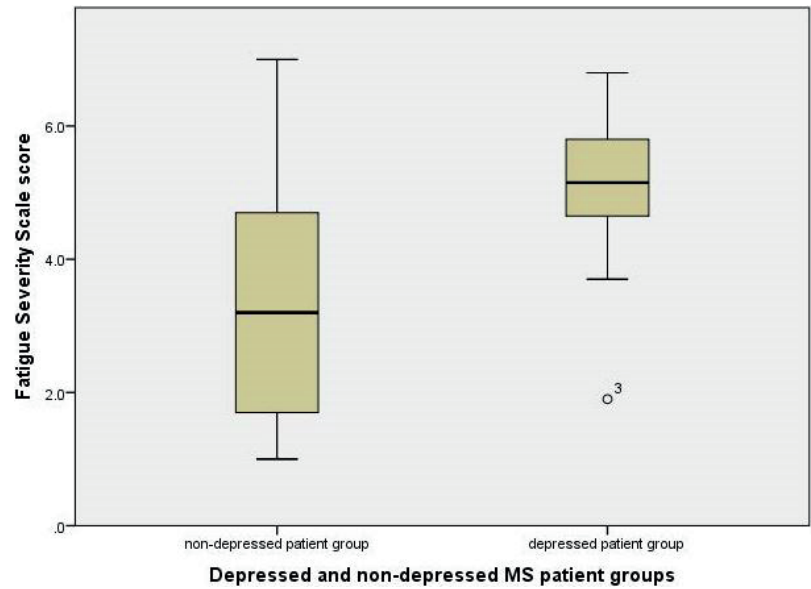

Fig. 3. Association between depressed and non-depressed groups and level of fatigue in MS patients

cause of the low consumption of alcohol among most of the MS patients, it is difficult to compare the results obtained. Recent studies show that alcohol (beer, wine or liquor) consumption is not associated to $\mathrm{MS}$ risk [20, 21]. However, alcohol should be considered as a molecule that interferes with the normal metabolism and facilitates the inflammatory process, complicating the possibility of improving the wellbeing of the patient [22].

Current studies suggest that persons with MS may have significantly more sleep problems than the general population, though prevalence estimates range from 25 to $54 \%$ [23-25]. Sleep disorders in MS and in the general population have a close association with symptoms of fatigue [26-28]. However, there was no association of sleep duration or daytime sleeping with fatigue in our study.

We did not find any association between fatigue and demographic factors, education level, physical activity, and pet ownership, unlike in the HOLISM study, where numerous demographic factors were associated with clinically significant fatigue. The factors distinguished among them included older age, female gender, and lower level of education [16]. Regarding physical activity, there is growing evidence that exercise affects fatigue in people with MS and vice versa [29]. It is therefore imperative to encourage exercise and physical activity from an early stage of the disease in the MS population.

Although it is hard to differentiate causes of fatigue in MS patients, correlation of fatigue with disability and depression in this study suggests the role of interplay between these clinical factors.

Higher fatigue rating was associated with a higher disability score in our study. Neurological disability measured by EDSS was also strongly related to fatigue in other studies [30-35]. But there are studies which demonstrate that perception of fatigue occurs in MS independently of the neurological impairment [36-38]. We should consider that assessing cerebral functional system score which is a part of EDSS, fatigue is already evaluated on a scale from 0 to 3 . If a patient is severely fatigued (reduction of daily activities more than $50 \%$ ) it affects total EDSS score respectively. However, total EDSS score in presence of pathological fatigue is only 2.0 if 
other functional systems are not affected. Presence of fatigue in our MS patient group was in different levels of disability and probably was affected by secondary factors.

We found an association between disability and depression, and the level of physical activity. Neurological impairment explains the decline in physical activity, which in its turn could provoke development of mood disorders.

The prevalence of depression or depressive disorder in multiple sclerosis patients in meta-analysis which included 58 articles with a total sample size of 87,756 MS patients, was $30.5 \%$ [39]. In our study we obtained similar results $27.9 \%$ of MS patients were depressed. An association between fatigue and depression was found, similar to the results obtained in other studies that showed correlation between depression and fatigue [33, 34, 36, 37, 40, 41]. Depressive symptoms increase the fatigue either directly or as a result of its psychological consequences [42-45]. Depressive mood may be interpreted as a reaction to being ill or as the result of (left) frontal neurodegeneration [46]. It has been argued that fatigue and depression in MS are both symptoms associated with similar neurobiological pathways [47]. Depression in MS patients is related to lower quality of life, cognitive dysfunction, elevated suicide risk, and working problems [48, 49]. Since depression in MS seems to worsen over time and as it is often treatable, early recognition is important and knowledge of its presence and management should be further improved in order to enhance clinical care [50-52]. Further studies are needed to determine whether depression treatment also improves fatigue in MS patients and whether antidepressant medications improve fatigue even in the absence of depression.

\section{CONCLUSIONS}

The results obtained in this study show that fatigue is a common symptom in MS patients of Latvia. Analyzing lifestyle habits in MS patient group, smoking patients were more fatigued than non-smoking patients, whereas other lifestyle factors did not show statistically significant associations with fatigue. In view of the above-mentioned findings, patients should be advised to give up smoking. Positive moderate correlations of fatigue with neurological disability and depression were confirmed, suggesting the role of these clinical factors leading to fatigue. Therefore, clinicians should increase awareness of modifiable factors and consider the interrelationship between these symptoms when treating either of them as it may be important for early therapeutic and prophylactic interventions.

\section{References}

1. Browne P, Chandraratna D, Angood C, et al. Atlas of Multiple Sclerosis 2013: A growing global problem with widespread inequity. Neurology 2014; 83(11): 1022-4. https://doi.org/10.1212/WNL.0000000000000768

2. Krupp LB, LaRocca NG, Muir-Nash J, Steinberg AD. The fatigue severity scale. Application to patients with multiple sclerosis and systemic lupus erythematosus. Arch
Neurol 1989; 46(10): 1121-3. https://doi.org/10.1001/ archneur.1989.00520460115022

3. Krupp LB. Fatigue in multiple sclerosis: definition, pathophysiology and treatment. CNS Drugs 2003; 17(4): 225-34. https://doi.org/10.2165/00023210-200317040-00002

4. Braley TJ, Chervin RD. Fatigue in multiple sclerosis: mechanisms, evaluation, and treatment. Sleep 2010; 33(8): 1061-7. https://doi.org/10.1093/sleep/33.8.1061

5. Tabrizi FM, Radfar M. Fatigue, sleep quality, and disability in relation to quality of life in multiple sclerosis. Int J MS Care 2015; 17(6): 268-74. https://doi.org/10.7224/ 1537-2073.2014-046

6. Julian LJ, Vella L, Vollmer T, Hadjimichael O, Mohr DC. Employment in multiple sclerosis: Exiting and re-entering the work force. Journal of Neurology 2008; 255(9): 1354-60. https://doi.org/10.1007/s00415-008-0910-y

7. Patejdl R, Penner IK, Noack TK, Zettl UK. Multiple sclerosis and fatigue: A review on the contribution of inflammation and immune-mediated neurodegeneration. Autoimmun Rev 2016; 15(3): 210-20. https://doi.org/10.1016/ j.autrev.2015.11.005

8. Feinstein A, Magalhaes S, Richard J-F, Audet B, Moore C. The link between multiple sclerosis and depression. Nat Rev Neurol 2014; 10(9): 507-17. https://doi.org/10.1038/ nrneurol.2014.139

9. Sadovnick AD, Remick RA, Allen J, et al. Depression and multiple sclerosis. Neurology 1996; 46(3): 628-32. https://doi.org/10.1212/WNL.46.3.628

10. Wells KB, Golding JM, Burnam MA. Psychiatric disorder in a sample of the general population with and without chronic medical conditions. Am J Psychiatry 1988; 145(8): 976-81. https://doi.org/10.1176/ajp.145.8.976

11. Polman CH, Reingold SC, Banwell B, et al. Diagnostic criteria for multiple sclerosis: 2010 Revisions to the McDonald criteria. Annals of Neurology 2011; 69(2): 292-302. https://doi.org/10.1002/ana.22366

12. Kurtzke JF. Rating neurologic impairment in multiple sclerosis: an expanded disability status scale (EDSS). Neurology 1983; 33(11): 1444-52. https://doi.org/10.1212/ WNL.33.11.1444

13. Ferrando SJ, Samton J, Mor N, Nicora S, Findler M, Apatoff B. Patient Health Questionnaire-9 to screen for depression in outpatients with multiple sclerosis. International Journal of MS Care 2007; 9(3): 99-103. https://doi.org/ 10.7224/1537-2073-9.3.99

14. Arroll B, Goodyear-Smith F, Grengle S, et al. Validation of PHQ-2 and PHQ-9 to screen for major depression in the primary care population. Annals of Family Medicine 2010; 8(4): 348-53. https://doi.org/10.1370/afm.1139

15. Tellez N, Rio J, Tintore M, Nos C, Galan I, Montalban X. Fatigue in multiple sclerosis persists over time: a longitudinal study. J Neurol 2006; 253(11): 1466-70. https://doi.org/ 10.1007/s00415-006-0247-3

16. Weiland TJ, Jelinek GA, Marck CH, et al. Clinically significant fatigue: prevalence and associated factors in an international sample of adults with multiple sclerosis recruited via the internet. PLoS One 2015; 10(2): e0115541. https://doi.org/10.1371/journal.pone.0115541

17. Fritz H-C, Wittfeld K, Schmidt CO, et al. Current smoking and reduced gray matter volume - a voxel-based morphometry study. Neuropsychopharmacology 2014; 39(11): 2594-600. https://doi.org/10.1038/npp.2014.112

18. De Stefano N, Airas L, Grigoriadis N, et al. Clinical relevance of brain volume measures in multiple sclerosis. CNS 
Drugs 2014; 28(2): 147-56. https://doi.org/10.1007/ s40263-014-0140-z

19. Stroup T. Multiple sclerosis and smoking. 2015. https://www.nationalmssociety.org/NationalMSSociety/ media/MSNationalFiles/Research/Stroup_T_Smoking_and _MS_20151110.pdf. Accessed February 28, 2017.

20. Massa J, O'Reilly EJ, Munger KL, Ascherio A. Caffeine and alcohol intakes have no association with risk of multiple sclerosis. Mult Scler 2013; 19(1): 53-8. https://doi.org/10.1177/ 1352458512448108

21. Hedström AK, Hillert J, Olsson T, Alfredsson L. Alcohol as a modifiable lifestyle factor affecting multiple sclerosis risk. JAMA Neurol 2014; 71(3): 300-5. https://doi.org/10.1001/ jamaneurol.2013.5858

22. Riccio P, Rossano R. Nutrition facts in multiple sclerosis. ASN Neuro 2015; 7(1): 1-20. https://doi.org/10.1177/ 1759091414568185

23. Neau JP, Paquereau J, Auche V, et al. Sleep disorders and multiple sclerosis: a clinical and polysomnography study. Eur Neurol 2012; 68(1): 8-15. https://doi.org/10.1159/ 000335076

24. Pokryszko-Dragan A, Bilińska M, Gruszka E, Biel Ł, Kamińska K, Konieczna K. Sleep disturbances in patients with multiple sclerosis. Neurol Sci 2013; 34(8): 1291-6. https://doi.org/10.1007/s10072-012-1229-0

25. Leonavicius R, Adomaitiene V. Features of sleep disturbances in multiple sclerosis patients. Psychiatr Danub 2014; 26(3): 249-55.

26. Merlino G, Fratticci L, Lenchig C, et al. Prevalence of 'poor sleep' among patients with multiple sclerosis: an independent predictor of mental and physical status. Sleep Med 2009; 10(1): 26-34. https://doi.org/10.1016/j.sleep.2007.11.004

27. Kaynak H, Altintaş A, Kaynak D, et al. Fatigue and sleep disturbance in multiple sclerosis. Eur J Neurol 2006; 13(12): 1333-9. https://doi.org/10.1111/j.1468-1331. 2006.01499.x

28. Merkelbach S, Schulz H, Group FCS. What have fatigue and sleepiness in common? J Sleep Res 2006; 15(1): 105-6. https://doi.org/10.1111/j.1365-2869.2006.00508.x

29. Motl RW, Suh Y, Weikert M, Dlugonski D, Balantrapu S, Sandroff B. Fatigue, depression, and physical activity in relapsing-remitting multiple sclerosis: Results from a prospective, 18-month study. Mult Scler Relat Disord 2012; 1(1): 43-8. https://doi.org/10.1016/j.msard.2011.08.003

30. Kroencke DC, Lynch SG, Denney DR. Fatigue in multiple sclerosis: relationship to depression, disability, and disease pattern. Mult Scler 2000; 6(2): 131-6. https://doi.org/ $10.1177 / 135245850000600213$

31. Strober LB, Arnett PA. An examination of four models predicting fatigue in multiple sclerosis. Arch Clin Neuropsychol 2005; 20(5): 631-46. https://doi.org/10.1016/ j.acn.2005.04.002

32. Pittion-Vouyovitch S, Debouverie M, Guillemin F, Vandenberghe N, Anxionnat R, Vespignani H. Fatigue in multiple sclerosis is related to disability, depression and quality of life. J Neurol Sci 2006; 243(1-2): 39-45. https://doi.org/10.1016/j.jns.2005.11.025

33. Bakshi R, Shaikh ZA, Miletich RS, et al. Fatigue in multiple sclerosis and its relationship to depression and neurologic disability. Mult Scler 2000; 6(3): 181-5. https://doi.org/ $10.1177 / 135245850000600308$

34. Kaya Aygünoğlu S, Çelebi A, Vardar N, Gürsoy E. Correlation of fatigue with depression, disability level and quality of life in patients with multiple sclerosis. Archives of Neuro-
psychiatry/Noropsikiatri Arsivi 2015; 52(3): 247-51. https://doi.org/10.5152/npa.2015.8714

35. Wood B, van der Mei IA, Ponsonby AL, et al. Prevalence and concurrence of anxiety, depression and fatigue over time in multiple sclerosis. Mult Scler 2013; 19(2): 217-24. https://doi.org/10.1177/1352458512450351

36. Alvarenga-Filho H, Papais-Alvarenga RM, Carvalho SR, Clemente HN, Vasconcelos CC, Dias RM. Does fatigue occur in MS patients without disability? Int J Neurosci 2015; 125(2): 107-15. https://doi.org/10.3109/ 00207454.2014 .909415

37. Téllez N, Río J, Tintoré M, Nos C, Galán I, Montalban X. Does the Modified Fatigue Impact Scale offer a more comprehensive assessment of fatigue in MS? Mult Scler 2005; 11(2): 198-202. https://doi.org/10.1191/ $1352458505 \mathrm{~ms} 1148 \mathrm{oa}$

38. Fisk JD, Pontefract A, Ritvo PG, Archibald CJ, Murray TJ. The impact of fatigue on patients with multiple sclerosis. Can J Neurol Sci 1994; 21(1): 9-14. https://doi.org/10.1017/ S0317167100048691

39. Boeschoten RE, Braamse AMJ, Beekman ATF, Cuijpers P, van Oppen P, Dekker J, et al. Prevalence of depression and anxiety in Multiple Sclerosis: A systematic review and meta-analysis. Journal of the Neurological Sciences 2017; 372: 331-41. https://doi.org/10.1016/j.jns.2016.11.067

40. Sabanagic-Hajric S, Suljic E, Kucukalic A. Fatigue during multiple sclerosis relapse and its relationship to depression and neurological disability. Psychiatr Danub 2015; 27(4): 406-12.

41. Hildebrandt H, Eling P. A longitudinal study on fatigue, depression, and their relation to neurocognition in multiple sclerosis. J Clin Exp Neuropsychol 2014; 36(4): 410-7. https://doi.org/10.1080/13803395.2014.903900

42. Schwartz CE, Coulthard-Morris L, Zeng Q. Psychosocial correlates of fatigue in multiple sclerosis. Arch Phys Med Rehabil 1996; 77(2): 165-70. https://doi.org/10.1016/ S0003-9993(96)90162-8

43. Randolph JJ, Arnett PA. Depression and fatigue in relapsing-remitting MS: the role of symptomatic variability. Mult Scler 2005; 11(2): 186-90. https://doi.org/10.1191/ $1352458505 \mathrm{~ms} 1133 \mathrm{oa}$

44. Rasova K, Brandejsky P, Havrdova E, Zalisova M, Rexova P. Spiroergometric and spirometric parameters in patients with multiple sclerosis: are there any links between these parameters and fatigue, depression, neurological impairment, disability, handicap and quality of life in multiple sclerosis? Mult Scler 2005; 11(2): 213-21. https://doi.org/10.1191/ $1352458505 \mathrm{~ms} 1155 \mathrm{oa}$

45. Unver V, Kilic B, Bolu A, et al. An analysis of the fatigue related factors and coping strategies in multiple sclerosis patients. European Journal of Internal Medicine 2011; 22: S96. https://doi.org/10.1016/S0953-6205(11)60391-9

46. Feinstein A, Roy P, Lobaugh N, et al. Structural brain abnormalities in multiple sclerosis patients with major depression. Neurology 2004; 62: 586. https://doi.org/10.1212/ 01.WNL.0000110316.12086.0C

47. Gold SM, Irwin MR. Depression and immunity: Inflammation and depressive symptoms in multiple sclerosis. Immunology and Allergy Clinics of North America 2009; 29(2): 309-20. https://doi.org/10.1016/j.iac.2009.02.008

48. Group GC. The Goldman Consensus statement on depression in multiple sclerosis. Mult Scler 2005; 11(3): 328-37. https://doi.org/10.1191/1352458505ms1162oa 
49. Fruehwald S, Loeffler-Stastka H, Eher R, Saletu B, Baumhackl U. Depression and quality of life in multiple sclerosis. Acta Neurol Scand 2001; 104(5): 257-61. https://doi.org/10.1034/j.1600-0404.2001.00022.x

50. Minden SL, Feinstein A, Kalb RC, et al. Evidence-based guideline: assessment and management of psychiatric disorders in individuals with MS: report of the Guideline Development Subcommittee of the American Academy of Neurology. Neurology 2014; 82(2): 174-81. https://doi.org/ 10.1212/WNL.0000000000000013

51. Hind D, Cotter J, Thake A, et al. Cognitive behavioural therapy for the treatment of depression in people with multiple sclerosis: a systematic review and meta-analysis. BMC Psychiatry 2014; 14: 5. https://doi.org/10.1186/1471-244X-14-5

52. Koch MW, Patten S, Berzins S, et al. Depression in multiple sclerosis: a long-term longitudinal study. Mult Scler 2015; 21(1): 76-82. https://doi.org/10.1177/1352458514536086

\section{S. Šetlere, A. Abelsen, D. Pastare, A. Millers}

\section{SERGANČIŲJŲ IŠSĖTINE SKLEROZE NUOVARGIS IR SUSIJĘ VEIKSNIAI LATVIJOJE}

\section{Santrauka}

İvadas ir tikslai. Nuovargis yra vienas dažniausių išsėtinės sklerozės (IS) simptomų. Šio tyrimo tikslas buvo nustatyti nuovargio dažnumą tarp IS sergančių pacientų Latvijoje ir jo ryšį su gyvensenos veiksniais, neurologine negalia ir depresija.

Tiriamieji ir tyrimo metodai. İ ši skerspjūvio tyrimą buvo įtraukta 117 tiriamujuc (44 IS sergantys ligoniai ir 73 sveiki kontroliniai asmenys). Taikyti tyrimo instrumentai buvo: Išplèstinè negalios ivvertinimo skale (Expanded Disability Status Scale, EDSS), Pacientų sveikatos klausimynas (PHQ-9), Nuovargio sunkumo skalè (Fatigue Severity Scale, FSS) ir socio-demografinių rodiklių, gyvenimo būdo ịpročių ir klinikinių duomenų klausimynas.

Rezultatai. FSS rezultatas IS grupèje buvo $3,9 \pm 1,9$. $26(59,1 \%)$ pacientų FSS rezultatas buvo 3,8 ar daugiau. Šie pacientai buvo priskirti nuovargio grupei (MSF). 18 (40,9\%) pacientų FSS buvo 3,7 ar mažiau. Šie pacientai buvo priskirti IS be reikšmingo nuovargio (MSNF) grupei. Statistiškai reikšmingas įverčių skirtumas tarp MSF ir MSNF grupių nustatytas PHQ-9 $(p=0,019)$, FSS $(p<0,001)$ ir EDSS $(p<0,001)$. Nustatyta reikšminga nuovargio koreliacija su depresija $(r=0,48, p=0,001)$, neurologine negalia $(r=0,49, p=0,001)$ ir rūkymu $(r=0,29$, $\mathrm{p}=0,054)$.

Išvados. Nuovargis yra dažnas simptomas tarp IS sergančiu pacientų Latvijoje. Šis tyrimas patvirtina reikšmingą nuovargio ir klinikinių veiksnių (negalios, depresijos) ir modifikuojamo gyvenimo būdo veiksnio - rūkymo ryšì.

Raktažodžiai: išsėtinè sklerozè, nuovargis, depresija.

Gauta:

20171123

Priimta spaudai: 20171219 